\title{
Differential signaling involved in Sutherlandia frutescens-induced cell death in MCF-7 and MCF-12A cells
}

Chris Vorster $^{1}$, Andre Stander $^{1}$, Annie Joubert ${ }^{1}$

\author{
Affiliation \\ ${ }^{1}$ Department of Physiology, School of Medicine, Faculty of Health Sciences, University of Pretoria, Pretoria, \\ South Africa
}

Corresponding author:

Prof. Annie Joubert, Department of Physiology, School of Medicine, Faculty of Health Sciences, University of Pretoria, Pretoria, 0001, South Africa. Email: annie.joubert@up.ac.za Phone: +27 828296281

\begin{abstract}
Ethnopharmacological relevance: The scientific study of natural products traditionally used in anticancer preparations has yielded several therapeutically relevant compounds. One of these traditional preparations with potentially beneficial properties is aqueous extracts of Sutherlandia frutescens, a shrub indigenous to the Western Cape region of South Africa. Aims of the study: To evaluate in vitro efficacy of these preparations on the MCF-7 breast adenocarcinoma and MCF-12A non-tumorigenic cell lines in terms of cell proliferation, cell morphology and possible induction of cell death.
\end{abstract}

Materials and Methods: Crystal violet staining was used to evaluate cell proliferation, lightand fluorescence microscopy were used to investigate both intracellular and extracellular morphological features of apoptosis and autophagy (e.g. membrane blebbing, condensed chromatin and intracellular lysosomes), while flow cytometry quantified cell cycle changes and induction of apoptosis through analysis of the flip-flop translocation of phosphatidylserine. 
Results: Crystal violet staining showed a time- and dose specific response to aqueous $S$. frutescens extracts, revealing exposure to $1 \mathrm{mg} / \mathrm{ml}$ aqueous extract for 48 hours to be ideal for comparing the differential effects of $S$. frutescens in the MCF-7 and MCF-12A cell lines. Microscopy showed distinct morphological changes with hallmarks of apoptosis being observed in both cell lines. Flow cytometry revealed a decrease in actively cycling cells in both cell lines, and a $4.36 \%$ increase in phosphatidylserine translocation in the MCF-7 cell line, indicative of apoptosis induction, while fluorescence microscopy showed evidence of the induction of autophagy.

Conclusions: Analyses revealed the carcinogenic MCF-7 cell line to be more susceptible to the cytostatic and cytotoxic effects of aqueous extracts of $S$. frutescens when compared to the non-tumorigenic MCF-12A cell line, thus warranting further research into the exact cellular mechanisms involved and the possible synergistic activities of $S$. frutescens ingredients.

\section{Classification:}

Malignant disease and immunosuppression

\section{Key words:}

Sutherlandia frutescens, cytotoxicity, cancer, ethnopharmacology, apoptosis, autophagy

\section{Introduction}

Cancer is one of the leading health risks in modern society and several avenues of research into possible alternative therapies are currently being pursued. One of the areas of cancer research which has made significant contributions towards improved cancer treatments is ethnopharmacology. The scientific study of natural products which have traditionally been used as antiproliferative preparations has yielded several compounds clinically relevant to 
modern antiproliferative therapy (Balunas and Kinghorn, 2005; da Rocha et al., 2001) and phytochemical therapy continues to be an area of active research (Neergheen et al., 2010). One of the traditional preparations which show promise is aqueous extracts of Sutherlandia frutescens (tribe Galegeae, Fabaceae), a shrub indigenous to South Africa, Lesotho, southern Namibia and south-eastern Botswana (van Wyk and Albrecht, 2008). It is traditionally used as a tea (aqueous extract) to remedy a variety of ailments ranging from cancer and diabetes to intestinal disease (Chinkwo, 2005; van Wyk and Gericke, 2000), and recently to improve the overall health of human immunodeficiency virus / acquired immunodeficiency syndrome (HIV/AIDS) patients (Klos et al., 2009; Brown et al., 2008; Harnett et al., 2005; Grandi et al., 2005; Morris, 2001). S. frutescens has been commercially cultivated on small scale since 1990 (van Wyk and Albrecht, 2008). More recently, Phyto Nova (Pty) Ltd (Cape Town, South Africa) started large scale cultivation and export of $S$. frutescens tablets, as well as a gel-based S. frutescens product for external anti-inflammatory and analgesic use (http://www.phyto-nova.co.za/).

Extracts of $S$. frutescens (water, ethanol, methanol, acetone, methylene dichloride) have demonstrated antiproliferative (Chinkwo, 2005), anti-HIV (Harnett et al., 2005), antidiabetic (Chadwick et al., 2007), anti-inflammatory, antibacterial (Katerere and Eloff, 2005), analgesic, anticonvulsant and antithrombotic activities. However, the molecular mechanisms of action of $S$. frutescens are still poorly characterized. Research into the chemical constitution of the plant has shown that $S$. frutescens contains large amounts of amino acids (notably L-arginine and L-canavanine), pinitol, flavonol glycosides and triterpenoid saponins (Moshe et. al., 1998) (van Wyk and Albrecht, 2008) (Shaik et al., 2010). L-canavanine replaces the structurally related amino acid L-arginine during protein synthesis, leading to non-functional proteins. L-arginine is a direct precursor of nitric oxide which has cytostatic 
and pro-apoptotic effects (Pervin et al., 2008). Pinitol is metabolised to D-chiro-inositol (3-0methyl-1,2,4-cis-3,5,6-trans-hexahydroxycyclohexanol) which has insulin-like activity, affecting glucose transport. Flavonol glycosides inhibit cytochrome P450 enzymes responsible for lipid and steroid catalysis (Androutsopoulos et al., 2010), while triterpenoid saponin metabolites exert cytotoxic effects on tumour cells (Chan, 2007).It has been demonstrated in our laboratory that ethanolic extracts of S. frutescens induce an S-phase cell cycle arrest, apoptosis and autophagy in cultured breast adenocarcinoma cells (Stander et al., 2009). Chinkwo (2005) showed that apoptosis induction occurred as a result of flip-flop translocation of the membrane protein phosphatidylserine. It is suspected that ethanolic and aqueous extracts of $S$. frutescens have significantly different chemical constituents and would thus have different effects on the cellular physiology of both normal and transformed cells. Furthermore, it has been suggested that a group of compounds, rather than a single active ingredient, is responsible for cytotoxic effects observed. Given the widespread traditional use and therapeutic potential of $S$. frutescens, further research into the exact mechanisms of the actions exerted by $S$. frutescens extracts is warranted. Thus, the aim of this study was to evaluate aqueous $S$. frutescens extracts for cancer research potential and to investigate and elucidate the signaling mechanisms involved in $S$. frutescens-induced cell death.

\section{Materials and Methods}

\subsection{Cell lines}

The MCF-7 cell line is derived from a pleural effusion of human breast adenocarcinoma which is commercially available from Highveld Biological Pty. (Ltd.) (Sandringham, SA). The MCF-12A cell line is a non-tumorigenic epithelial cell line produced by long-term 
culture of normal mammary tissue. These cells were a gift from Prof. Parker (Department of Medical Biochemistry, University of Cape Town, Cape Town, SA).

\subsection{Materials}

Annexin V fluorescein isothiocyanate (FITC) staining kit was purchased from Miltenyi Biotec GmbH (Bergisch Gladbach, Germany). All other analytical grade reagents including cell culture media, sterile plates and flasks, actinomycin D, and the required reagents for crystal violet staining, haematoxylin and eosin staining, fluorescence microscopy and flow cytometric analyses, were obtained from either Sigma (St. Louis, USA) or Highveld Biological (Pty) Ltd. (Sandringham, South Africa).

\subsection{S. frutescens}

Dried leaves and small twigs of Sutherlandia frutescens (family: Fabaceae, subspecies Microphylla) were purchased from Ms. Eilleen Menne of Karoo Herbs (De Aar, South Africa). Specimens of $S$. frutescens were harvested and air-dried in the shade. Finely powdered $S$. frutescens leaves and twigs $(0.5 \mathrm{~g})$ were autoclaved and subsequently mixed to a final volume of $10 \mathrm{ml}$ with deionized boiling water and left overnight at room temperature. The extract was centrifuged for $10 \mathrm{~min}$ at $1000 \times g(2500 \mathrm{rpm})$ and the supernatant was removed and filtered using a $0.2 \mu \mathrm{m}$ filter providing a stock solution extract of $0.05 \mathrm{~g} / \mathrm{ml}$ as previously described (Stander et al., 2009).

\subsection{Cell cultures}

MCF-7 cells were cultured in Dulbecco's Modified Eagle's Medium (DMEM) supplemented with $10 \%$ fetal bovine serum (FCS), penicillin $(100 \mu \mathrm{g} / \mathrm{l})$, streptomycin $(100 \mu \mathrm{g} / \mathrm{l})$ and fungizone $(250 \mu \mathrm{g} / \mathrm{l})$. MCF-12A cells were propagated in a medium containing a 1:1 mixture of DMEM and Ham's-F12 medium, $20 \mathrm{ng} / \mathrm{ml}$ epidermal growth factor, $100 \mathrm{ng} / \mathrm{ml}$ cholera toxin, $10 \mu \mathrm{g} / \mathrm{ml}$ insulin and $500 \mathrm{ng} / \mathrm{ml}$ hydrocortisone, supplemented with $10 \%$ heat- 
inactivated FCS $\left(56^{\circ} \mathrm{C}, 30 \mathrm{~min}\right), 100 \mathrm{U} / \mathrm{ml}$ penicillin $\mathrm{G}, 100 \mu \mathrm{g} / \mathrm{ml}$ streptomycin and fungizone $(250 \mu \mathrm{g} / \mathrm{l})$. Cells were propagated at $37^{\circ} \mathrm{C}$ in a humidified $5 \%$ carbon dioxide environment. After seeding an appropriate number of cells, flasks and plates were left overnight to allow cell attachment. All experiments included the appropriate controls in the form of cells propagated in growth medium (MO) and cells exposed to equivalent volumes of distilled, deionized water $\left(\mathrm{ddH}_{2} \mathrm{O}\right.$ at $\left.0.05 \%-0.25 \% \mathrm{v} / \mathrm{v}\right)$ which served as the vehicle control. Positive controls for apoptosis (actinomycin D) and autophagy (cells starved by culturing in $20 \%$ medium and $80 \%$ phosphate buffered saline) were included in each experiment and culture medium was changed before exposure.

\subsection{Cell numbers - Crystal violet}

Time- $(24,48,72$ hours $)$ and dose- $(0.5-2.5 \mathrm{mg} / \mathrm{ml})$ dependent cell proliferation studies were conducted in order to determine the optimal exposure parameters for observation of the effects investigated in this study when comparing the results from the MCF-7 and MCF-12A cell lines. The initial reagent concentrations and times of exposure to $S$. frutescens extracts were selected to correlate with previous literature and studies conducted in our laboratory (Vorster et al., 2010; Stander et al., 2007; Chinkwo, 2005; Tai et al., 2004). Cells were seeded at 5000 cells per well in 96 -well plates and incubated overnight at $37^{\circ} \mathrm{C}$ in a humidified, $5 \%$ $\mathrm{CO}_{2}$ environment to allow for attachment. Baseline values were determined before exposure to $S$. frutescens in order to quantify starting cell numbers. Cells were then exposed to the selected concentrations $(0.5-2.5 \mathrm{mg} / \mathrm{ml})$ of $S$. frutescens for 24,48 and 72 hours, after which the experiment was terminated by removal of the medium and fixation of cells using $1 \%$ glutaraldehyde for 15 minutes. Cells were then stained for 30 minutes with $0.1 \%$ crystal violet. The 96-well plates were subsequently washed under slowly running tap water to remove excess stain and dried at room temperature overnight. Dried plates were exposed to 
$0.2 \%$ Triton $\mathrm{X}-100$ at room temperature for 30 minutes to solubilize the crystal violet. After mixing, $100 \mu 1$ of the solution was transferred to a clean $96-$ well plate and the absorbance was read using an ELX-800 Universal Microplate Reader (Bio-Tek Instruments, Winooski, USA). After half maximal growth inhibitory concentration $\left(\mathrm{GI}_{50}\right)$ values were calculated all subsequent experiments were conducted utilizing an exposure time of 48 hours at $1 \mathrm{mg} / \mathrm{ml} S$. frutescens, as these parameters presented the most significantly differential results in MCF-7 breast adenocarcinoma cells when compared to the non-tumorigenic MCF-12A breast epithelial cell line.

\subsection{Morphology}

\subsubsection{Differential Interference Contrast Microscopy}

Differential interference contrast (DIC) microscopy relies on a beam of polarized light being split into two beams, polarized at $90^{\circ}$ with regard to each other, each beam taking a different path through the sample. Variations in the optical density of the sample causes interference between the two beams, which are then recombined resulting in a three-dimensional relief of the sample. This non-invasive technique was utilized to evaluate the qualitative status of cell populations at various times during exposure. DIC images illustrated in this article were taken of cells just prior to fixation for haematoxylin and eosin staining. Evaluation was conducted at both 100X and 400X magnifications with a Zeiss inverted Axiovert CFL40 microscope equipped with a PlasDIC (polarization differential interference contrast) filter and photomicrographs were taken with a Zeiss Axiovert MRm monochrome camera (Carl Zeiss MicroImaging, Inc., New York, USA). 


\subsubsection{Haematoxylin and Eosin staining}

$H \& E$ cell staining was conducted for qualitative evaluation of cellular morphology and to determine the mitotic indices for quantitation of cell cycle shift and abnormal morphology. The methodology utilized in this study has been standardized in our laboratory (Vorster et al., 2010). Cells were seeded on heat-sterilized coverslips in 6-well plates at a density of 250000 cells per well and allowed to attach overnight. Cells were subsequently exposed to $1 \mathrm{mg} / \mathrm{ml} S$. frutescens and appropriate controls respectively for 48 hours, after which coverslips were fixed with Bouin's fixative (30 minutes) and 70\% ethanol (20 minutes). Coverslips were rinsed with tap water, stained with haematoxylin (20 minutes), rinsed (tap water and 70\% ethanol) and stained with eosin (7 minutes). Coverslips were then dehydrated stepwise with ethanol $(70 \%, 96 \%, 100 \%)$ and xylene, mounted on microscope slides with Entellan resin and dried overnight. Qualitative evaluation (100X and 400X magnification) was conducted with a Zeiss inverted Axiovert CFL40 microscope and photomicrographs were taken with a Zeiss Axiovert MRm monochrome camera (Carl Zeiss MicroImaging, Inc., New York, USA). Mitotic index counts were determined, with individual cells being divided into different phases of the cell cycle based on morphological characteristics. Cells which could not be categorized due to excessive fragmentation, highly unusual nuclear morphology or lack of clear nuclear material were defined and counted as 'abnormal'. The experiment was repeated three times and 1000 cells were counted per slide. Data was converted to represent percentages of cells present in each defined category providing representative statistics.

\subsubsection{Fluorescence microscopy}

Fluorescent staining with a combination of Hoechst 33342, acridine orange (AO) and propidium iodide (PI) was conducted in order to quantify the acidic intracellular vacuoles (lysosomes or autophagosomes) associated with autophagy. Hoechst 33342 stains cell nuclei, 
AO accumulates in acidic intracellular vacuoles and PI concentrates in cells with damaged membranes (i.e. dead cells). Cells were seeded at 250000 cells per well in 6-well plates, allowed to attach overnight and exposed to $S$. frutescens or appropriate controls in fresh medium for 48 hours. Samples were then incubated with $0.9 \mu \mathrm{M}$ Hoechst 33342 and $50 \mu \mathrm{M}$ AO (30 minutes at $\left.37^{\circ} \mathrm{C}\right)$. Subsequently $12 \mu \mathrm{M}$ PI was added for a further 5 minutes, after which the cells were washed twice with PBS. Samples were examined under a Zeiss inverted Axiovert CFL40 microscope and photomicrographs were taken with a Zeiss Axiovert MRm monochrome camera (Carl Zeiss MicroImaging, Inc., New York, USA) using different fluorescence filters to distinguish between the stains. Images were then false-colored and composited with Zeiss AxioVision software. Zeiss Filter 2 was used for Hoechst 33342stained cells (blue emission) and Zeiss Filter 9 for acridine orange-stained cells (green emission).

\subsection{Flow cytometry}

Flow cytometry was used to confirm the observed cell cycle disturbances, to investigate the intracellular events causing these aberrations and to measure indications of apoptosis. Propidium iodide staining was used in order to analyze and quantify DNA-based cell cycle dynamics. FITC-labeled Annexin V was employed to measure the flip-flop translocation of the membrane phospholipid phosphatidylserine (PS) by the enzyme flippase, which occurs only during initiation of the apoptotic process. Annexin $\mathrm{V}$ is a $35-36 \mathrm{kDa}, \mathrm{Ca}^{2+}$-dependent, phospholipid binding protein with a high affinity for PS. Cells were seeded at 750000 cells

per flask in $25 \mathrm{~cm}^{2}$ flasks and allowed to attach overnight. Cells were exposed to S. frutescens and appropriate controls respectively for 48 hours, after which all cells and cellular debris were removed from culture flasks by trypsinization and fixed with $10 \mathrm{ml}$ ice-cold $70 \%$ ethanol and stored at $4^{\circ} \mathrm{C}$ for 24 hours. After 24 hours, cells were washed with PBS and 
Annexin V FITC staining was conducted according to manufacturer's instructions (Miltenyi Biotec $\mathrm{GmbH}$, Bergisch Gladbach, Germany). Cells $\left(1 \times 10^{6}\right)$ were washed and suspended in $0.5 \mathrm{ml}$ PBS containing $40 \mu \mathrm{g} / \mathrm{ml}$ propidium iodide (binds to nucleic acids, in this case DNA, enabling quantification of the nuclear material) and $100 \mu \mathrm{g} / \mathrm{ml}$ RNase A (for removal of RNA) for $30 \mathrm{~min}$ at $4^{\circ} \mathrm{C}$. Analyses were conducted using a Beckman Coulter Cytomics FC500 instrument (Beckman Coulter Inc., Fullerton, CA, United States of America). Aggregated and aneuploid cells were removed from analysis by visual inspection, with sub$\mathrm{G}_{1}$ indicating cells with less nuclear content than normal and cellular fragments, while abnormal cells were defined as cells with more than $2 \mathrm{~N}$ genetic content. For cell cycle analyses, results are expressed as percentage of the cells in each phase. Data from at least 10 000 cells were analyzed with CXP software (Beckman Coulter South Africa (Pty) Ltd). The experiment was repeated three times, and the data generated was analyzed and visualized using Cyflogic software (CyFlo Ltd. - http://www.cyflogic.com/).

\subsection{Statistical Analysis}

Data from three independent experiments (each conducted with six replicates for crystal violet experiments) were analysed. Quantitative data was statistically analyzed for significance using the single factor (one-way) analysis of variance (ANOVA) model and a two-tailed, homoscedastic Student's $t$-test, with $p$-values $<0.05$ being regarded as statistically significant. Means are presented in bar charts, with T-bars referring to standard deviations. For flow cytometric data experiments were repeated thrice, 10000 to 30000 events were counted per sample and percentages were calculated by gating the supplier-provided isotypic control to $<1 \%$. 


\section{Results}

\subsection{Crystal violet}

A time-and dose-dependent decrease in cell numbers was observed in response to $S$.

frutescens exposure (Fig. 1). A concentration of $1 \mathrm{mg} / \mathrm{ml}$ S. frutescens and an exposure time of 48 hours were selected for further analysis, since these were the $\mathrm{GI}_{50}$ parameters calculated for the MCF-7 breast adenocarcinoma cell line (51.79\% of control), while the MCF-12A nontumorigenic cell line was significantly less affected (93.22\% of control). The $\mathrm{GI}_{50}$ value indicates the concentration inhibiting growth in $50 \%$ of cells in the sample. All subsequent studies were conducted using these experimental parameters. Data is shown in table 1.

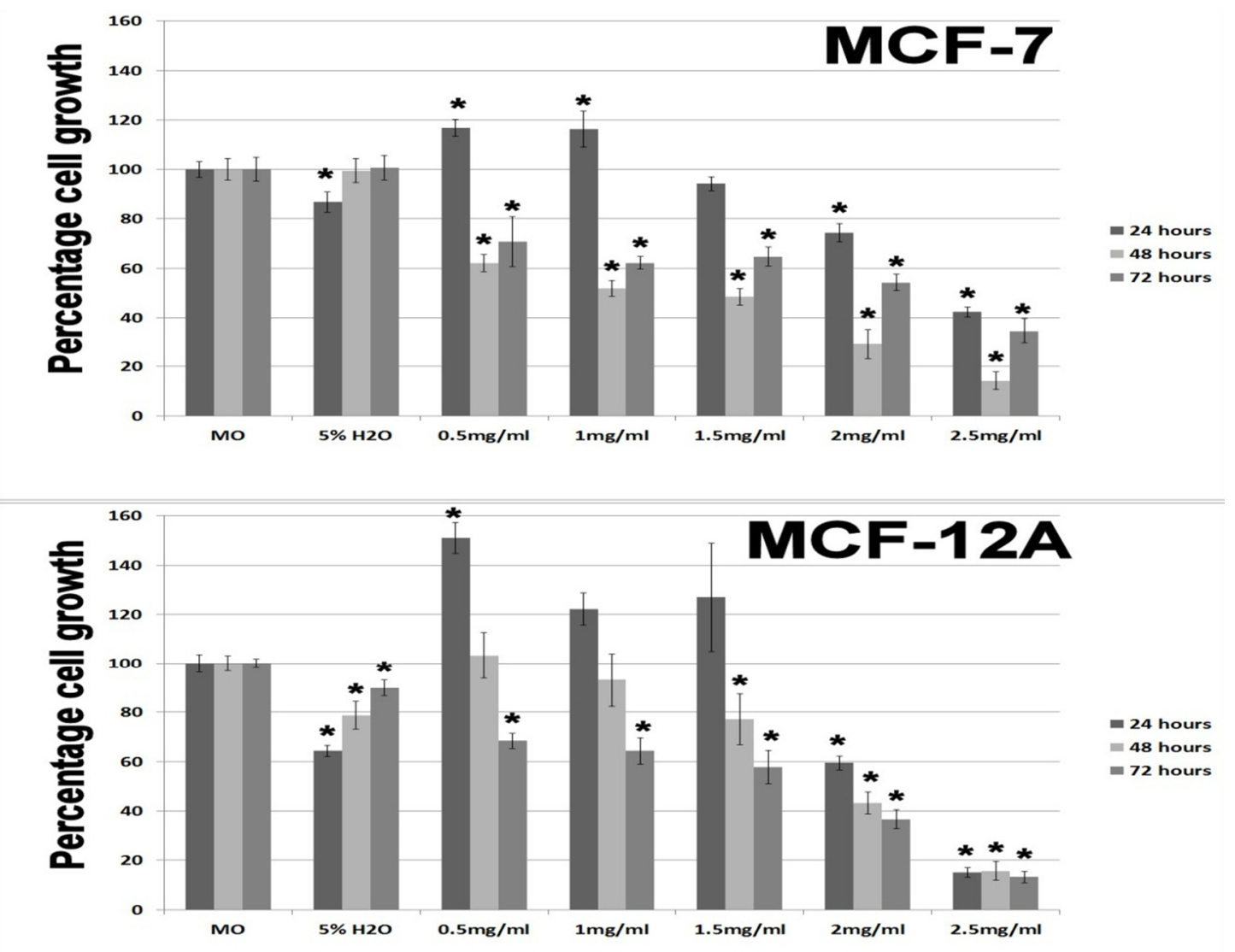

Figure 1: Crystal violet proliferation assay results for MCF-7 (top) and MCF-12A (bottom) cells, showing a time and dose dependent inhibition of cell growth. $0.5 \mathrm{mg} / \mathrm{ml}-2.5 \mathrm{mg} / \mathrm{ml}$ indicates the different concentrations of $S$. frutescens utilized. $5 \% \mathrm{H}_{2} \mathrm{O}$ is indicated as it was the highest concentration of vehicle control utilized. Samples showing statistically significant deviations from the medium only sample $(P$-value $<0.05)$ are indicated with asterisks. The most pronounced cell line-specific response to $S$. frutescens exposure when MCF-7 samples were compared to MCF-12A samples were observed after 48 hours at a concentration of $1 \mathrm{mg} / \mathrm{ml}$. 
Table 1: Statistical analysis of crystal violet assay data. Values given are inhibitory concentration $\left(\mathrm{IC}_{50}\right)$, growth inhibitory concentration $\left(\mathrm{GI}_{50}\right)$, lethal concentration $\left(\mathrm{LC}_{50}\right)$ and the P-value generated from the Student's $\boldsymbol{t}$-test.

\begin{tabular}{|c|c|c|c|c|c|c|}
\hline & & Sample & $\mathrm{IC}_{50}$ & $\mathrm{Gl}_{50}$ & $\mathrm{LC}_{50}$ & $P$-value \\
\hline \multirow{18}{*}{ MCF-7 } & \multirow{6}{*}{24 hours } & $5 \%$ H2O & 90.91483 & 86.81717 & 11.28874 & 0.00978759 \\
\hline & & $0.5 \mathrm{mg} / \mathrm{ml}$ & 111.56677 & 116.78369 & 36.56876 & 0.00184144 \\
\hline & & $1 \mathrm{mg} / \mathrm{ml}$ & 111.14616 & 116.17338 & 36.56876 & 0.04139825 \\
\hline & & $1.5 \mathrm{mg} / \mathrm{ml}$ & 96.00421 & 94.20200 & 36.05390 & 0.10314549 \\
\hline & & $2 \mathrm{mg} / \mathrm{ml}$ & 82.33438 & 74.36672 & 17.51864 & 0.00003360 \\
\hline & & $2.5 \mathrm{mg} / \mathrm{ml}$ & 60.25237 & 42.32512 & 0.78543 & 0.00000000 \\
\hline & \multirow{6}{*}{48 hours } & $5 \% \mathrm{H} 2 \mathrm{O}$ & 99.55400 & 99.47097 & 141.34442 & 0.89433172 \\
\hline & & $0.5 \mathrm{mg} / \mathrm{ml}$ & 68.06839 & 62.12365 & 65.01523 & 0.00000024 \\
\hline & & $1 \mathrm{mg} / \mathrm{ml}$ & 59.36073 & 51.79488 & 65.01523 & 0.00000002 \\
\hline & & $1.5 \mathrm{mg} / \mathrm{ml}$ & 56.54667 & 48.45692 & 43.90563 & 0.00000001 \\
\hline & & $2 \mathrm{mg} / \mathrm{ml}$ & 40.24636 & 29.12197 & 37.08363 & 0.00000000 \\
\hline & & $2.5 \mathrm{mg} / \mathrm{ml}$ & 27.66274 & 14.19563 & -2.43249 & 0.00000000 \\
\hline & \multirow{6}{*}{72 hours } & $5 \% \mathrm{H} 2 \mathrm{O}$ & 100.61762 & 100.70376 & 212.77151 & 0.86081478 \\
\hline & & $0.5 \mathrm{mg} / \mathrm{ml}$ & 74.44644 & 70.88237 & 131.41797 & 0.00024477 \\
\hline & & $1 \mathrm{mg} / \mathrm{ml}$ & 66.85500 & 62.23212 & 131.41797 & 0.00000015 \\
\hline & & $1.5 \mathrm{mg} / \mathrm{ml}$ & 69.04236 & 64.72456 & 107.81985 & 0.00000060 \\
\hline & & $2 \mathrm{mg} / \mathrm{ml}$ & 59.90690 & 54.31493 & 114.61931 & 0.00000004 \\
\hline & & $2.5 \mathrm{mg} / \mathrm{ml}$ & 42.53665 & 34.52197 & 86.22156 & 0.00000000 \\
\hline \multirow{18}{*}{ MCF-12A } & \multirow{6}{*}{24 hours } & $5 \% \mathrm{H} 2 \mathrm{O}$ & 84.38554 & 64.33401 & 50.09797 & 0.00031129 \\
\hline & & $0.5 \mathrm{mg} / \mathrm{ml}$ & 122.30637 & 150.95141 & 117.54837 & 0.00184636 \\
\hline & & $1 \mathrm{mg} / \mathrm{ml}$ & 109.70740 & 122.17330 & 117.54837 & 0.08255419 \\
\hline & & $1.5 \mathrm{mg} / \mathrm{ml}$ & 111.77281 & 126.89102 & 95.13838 & 0.46693618 \\
\hline & & $2 \mathrm{mg} / \mathrm{ml}$ & 82.23752 & 59.42758 & 98.81215 & 0.00006918 \\
\hline & & $2.5 \mathrm{mg} / \mathrm{ml}$ & 62.82272 & 15.08099 & 46.27725 & 0.00000005 \\
\hline & \multirow{6}{*}{48 hours } & $5 \% \mathrm{H} 2 \mathrm{O}$ & 84.57809 & 78.83993 & 211.89077 & 0.00111241 \\
\hline & & $0.5 \mathrm{mg} / \mathrm{ml}$ & 102.43084 & 103.33531 & 277.72471 & 0.66319403 \\
\hline & & $1 \mathrm{mg} / \mathrm{ml}$ & 95.05861 & 93.22003 & 277.72471 & 0.41879638 \\
\hline & & $1.5 \mathrm{mg} / \mathrm{ml}$ & 83.40252 & 77.22696 & 250.53882 & 0.01009025 \\
\hline & & $2 \mathrm{mg} / \mathrm{ml}$ & 58.59596 & 43.19041 & 207.55572 & 0.00000002 \\
\hline & & $2.5 \mathrm{mg} / \mathrm{ml}$ & 38.57138 & 15.71513 & 116.07886 & 0.00000000 \\
\hline & \multirow{6}{*}{72 hours } & $5 \% \mathrm{H} 2 \mathrm{O}$ & 92.24941 & 89.95616 & 304.02890 & 0.00281768 \\
\hline & & $0.5 \mathrm{mg} / \mathrm{ml}$ & 75.59066 & 68.36842 & 231.06784 & 0.00000009 \\
\hline & & $1 \mathrm{mg} / \mathrm{ml}$ & 72.48707 & 64.34653 & 231.06784 & 0.00000104 \\
\hline & & $1.5 \mathrm{mg} / \mathrm{ml}$ & 67.45422 & 57.82456 & 217.47490 & 0.00000082 \\
\hline & & $2 \mathrm{mg} / \mathrm{ml}$ & 51.09744 & 36.62814 & 195.43228 & 0.00000000 \\
\hline & & $2.5 \mathrm{mg} / \mathrm{ml}$ & 33.06305 & 13.25773 & 123.79378 & 0.00000000 \\
\hline
\end{tabular}




\subsection{PlasDIC microscopy}

PlasDIC microscopy revealed a decrease in cell numbers and density in $S$. frutescens-treated samples when compared to vehicle control samples in the MCF-7 cell line (100X magnification, data not shown), while only a slight increase in cytoplasmic vacuolization and some changes in nuclear morphology were observed in the MCF-12A cell line (Fig. 2). The MCF-7 breast adenocarcinoma samples appear to be more susceptible to $S$. frutescens exposure, with an increase in the number of cell fragments and cells displaying apoptotic characteristics being observed.
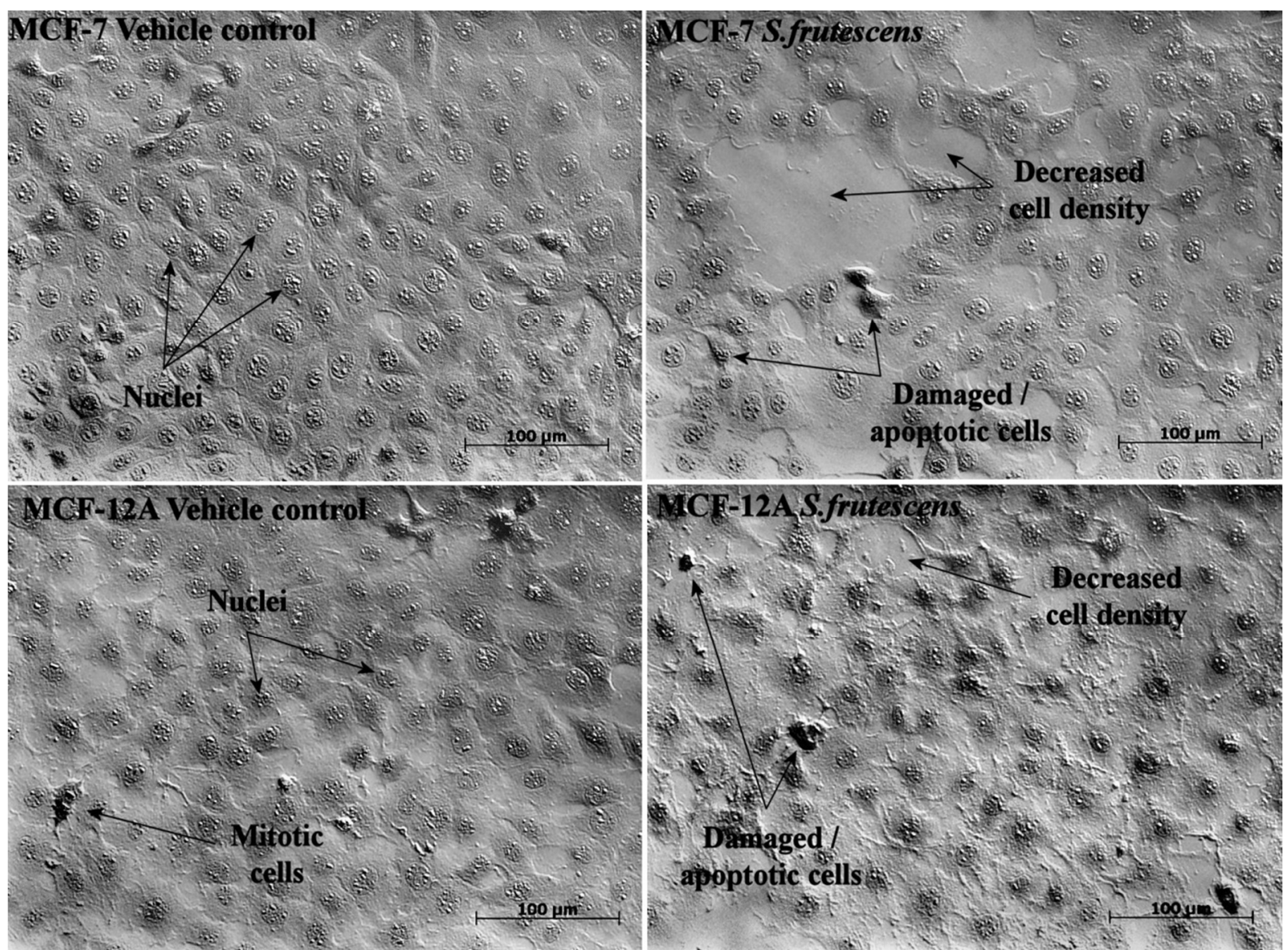

Figure 2: PlasDIC microscopic images (100X magnification) of MCF-7 (top) and MCF-12A (bottom) cells exposed to vehicle control $\left(\mathrm{H}_{2} \mathrm{O}\right)$ on the left, and cells exposed to $S$. frutescens extracts on the right. Note the decreased cell density and cellular damage in $S$. frutescens exposed samples of both cell lines. 


\subsection{Haematoxylin and Eosin staining}

\subsubsection{Microscopy}

Qualitative analysis by H\&E staining revealed decreased cell density and morphological changes in response to $S$. frutescens exposure in both cell lines, Cells displaying apoptotic characteristics (hypercondensed chromatin, membrane blebbing) were observed in samples of both cell lines exposed to S. frutescens (Fig. 3).
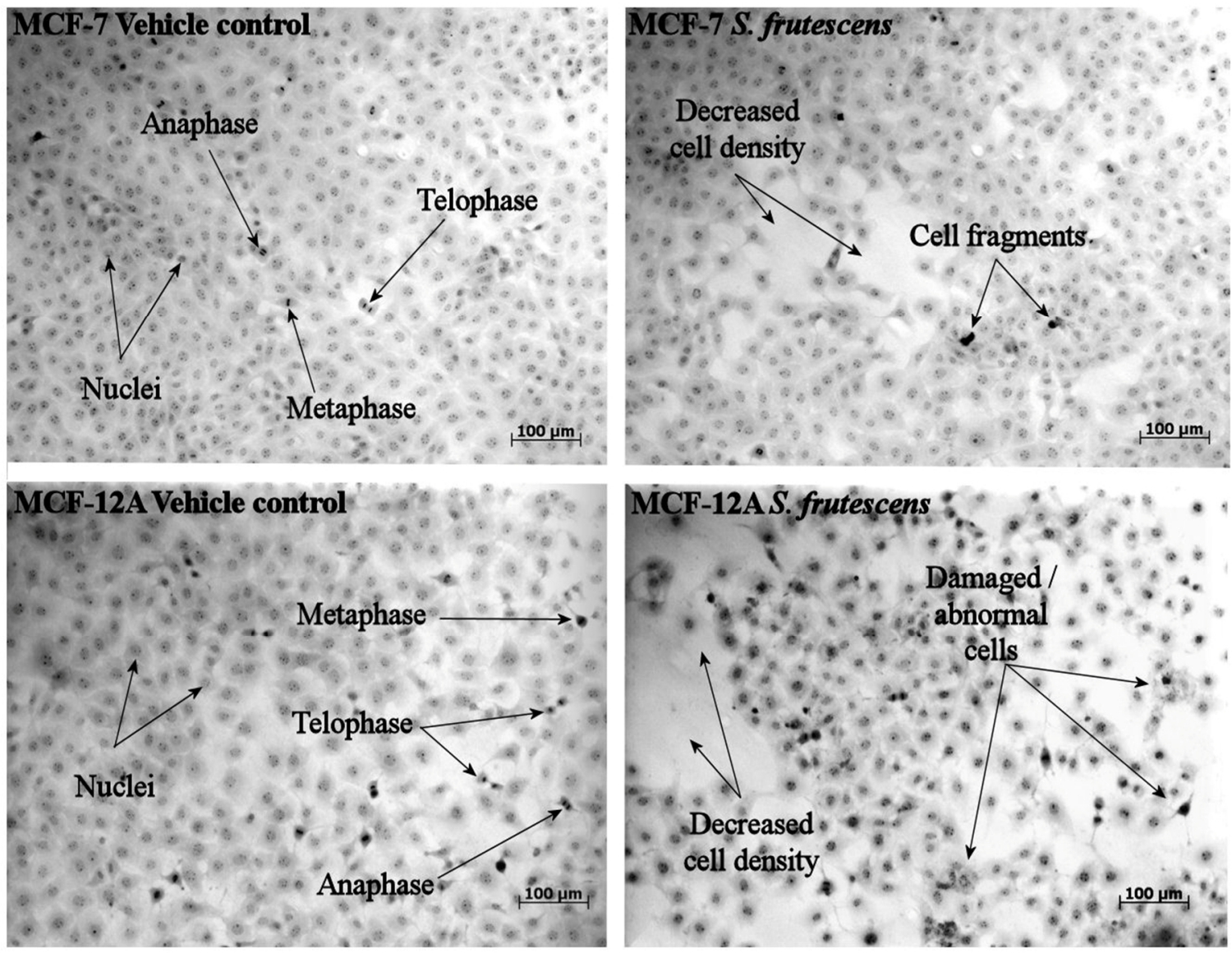

Figure 3: Photomicrographs of haematoxylin and eosin stained MCF-7 (top) and MCF-12A (bottom) cells (100X magnification) showing a marked decrease in cell density in cells exposed to $S$. frutescens extracts (right) when compared to cells exposed to vehicle control $\left(\mathrm{H}_{2} \mathrm{O}\right.$ - left).

\subsubsection{Mitotic indices}

Quantitative analyses revealed MCF-7 samples exposed to $S$. frutescens exhibiting a marked decrease in the percentage of cells in metaphase (M), anaphase (A) and telophase (T) when 
compared to vehicle control $\left(\mathrm{H}_{2} \mathrm{O}\right)$ samples, while an increase in the number of apoptotic cells was observed. This effect (increased number of apoptotic cells) was also observed in MCF-12A samples, however no significant perturbation of cell cycle dynamic was seen in the non-tumorigenic cell line (Fig. 4). 1000 cells were counted per slide, and absolute counts were converted to percentages. For clarity of comparison, interphase cells are not shown.

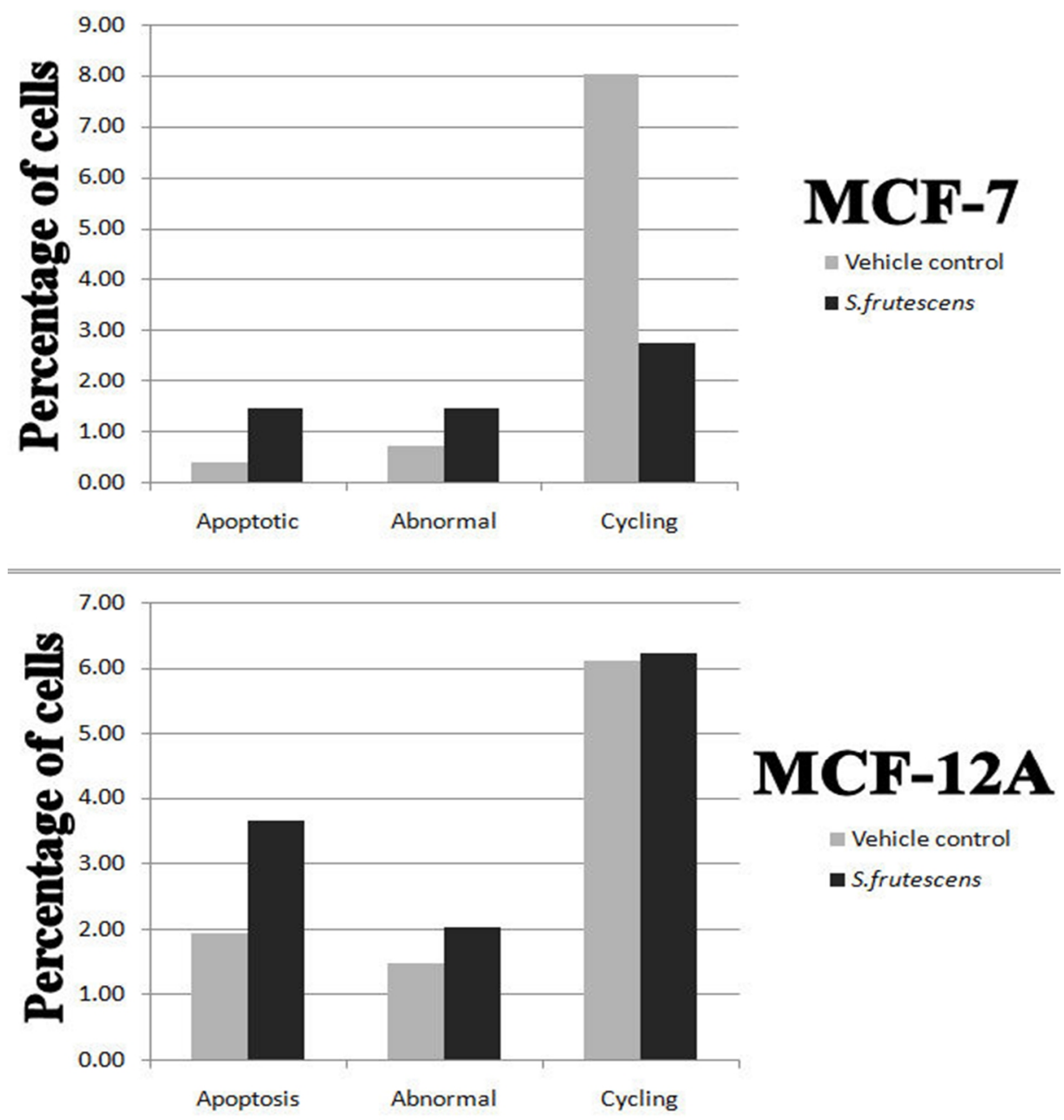

Figure 4: Mitotic indices for MCF-7 (top) and MCF-12A (bottom) cells exposed to vehicle control $\left(\mathrm{H}_{2} \mathrm{O}\right)$ and $S$. frutescens extracts respectively. Cells were visually counted after haematoxylin and eosin staining and divided into the following categories: apoptotic, abnormal and cycling (all mitotic cells). Both lines showed an increase in apoptotic and abnormal cells in response to $S$. frutescens exposure, however only MCF-7 samples showed a distinct decrease $(5.27 \%)$ in actively cycling cells. 


\subsection{Fluorescence microscopy}

Fluorescent triple-staining with Hoechst / acridine orange / propidium iodide showed a marked increase in acidic intracellular vacuoles in both the MCF-7 breast adenocarcinoma and MCF-12A non-carcinogenic cell lines in samples exposed to S. frutescens (increase in green acridine orange fluorescent intensity) (Fig. 5). This increase in acidic intracellular vesicle formation in response to $S$. frutescens exposure is indicative of autophagy induction.
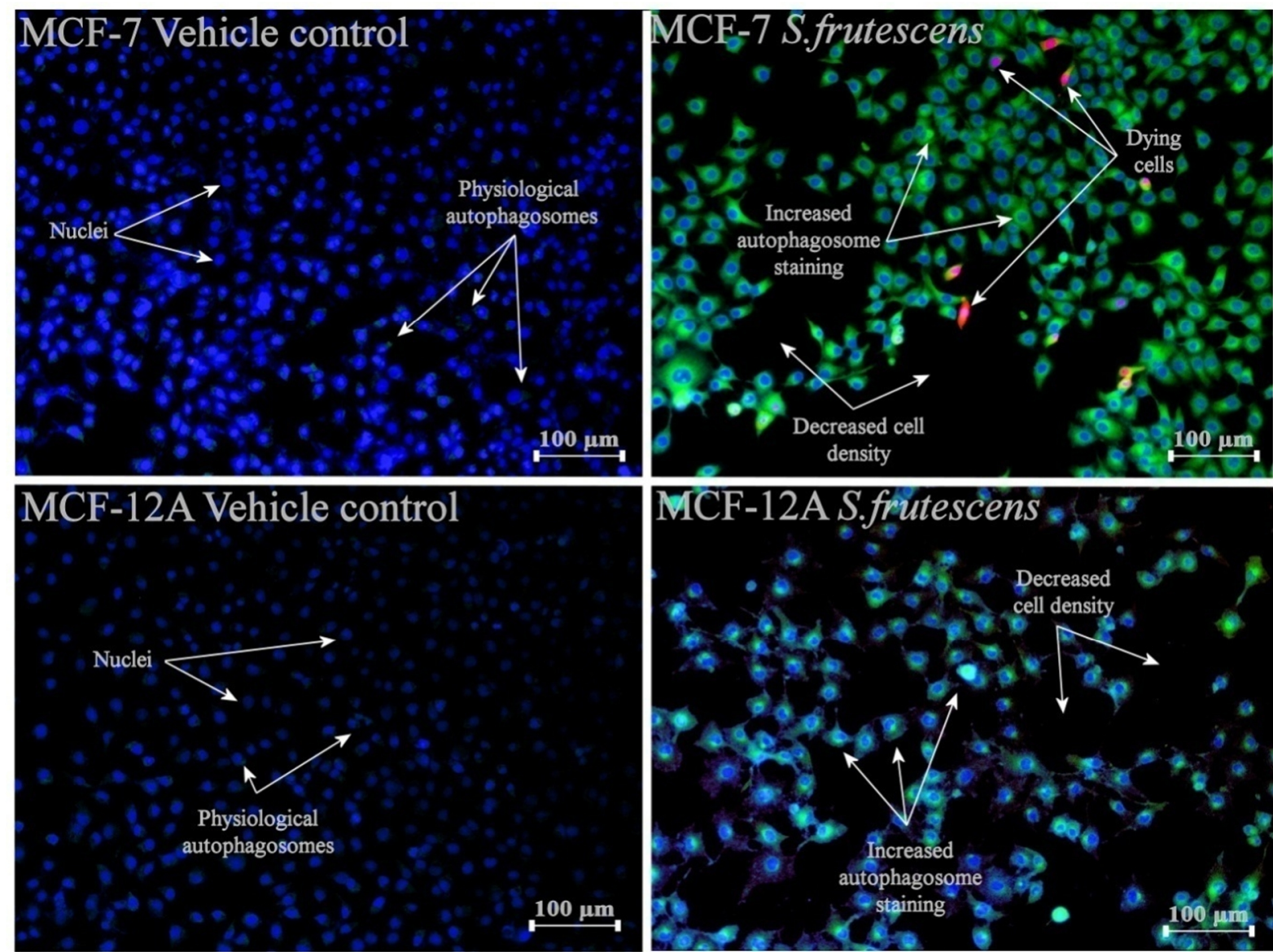

Figure 5: Fluorescence photomicrographs of MCF-7 (top) and MCF-12A (bottom) cells exposed to vehicle control $\left(\mathrm{H}_{2} \mathrm{O}\right)$ and $S$. frutescens extracts. Both cell lines exhibited an increase in acidic intracellular vesicle formation in response to $S$. frutescens exposure, however this effect was qualitatively much more pronounced in MCF-7 samples. 


\subsection{Flow cytometry}

\subsubsection{Cell Cycle analysis}

Flow cytometric analyses of cell cycle dynamics confirmed a distinct increase in $\mathrm{G}_{1^{-}}$ phase cells in the MCF-7 cell line (12.19\%), with a concurrent decrease in actively cycling cells (S- and $\mathrm{G}_{2} / \mathrm{M}$-phase) in response to $S$. frutescens exposure. The MCF$12 \mathrm{~A}$ cell line revealed a smaller $(4.82 \%)$, though statistically significant increase in $\mathrm{G}_{1}$-phase cells (Fig. 6). Data is shown in table 2. Cells with more than $2 \mathrm{~N}$ genetic content were classified as abnormal.

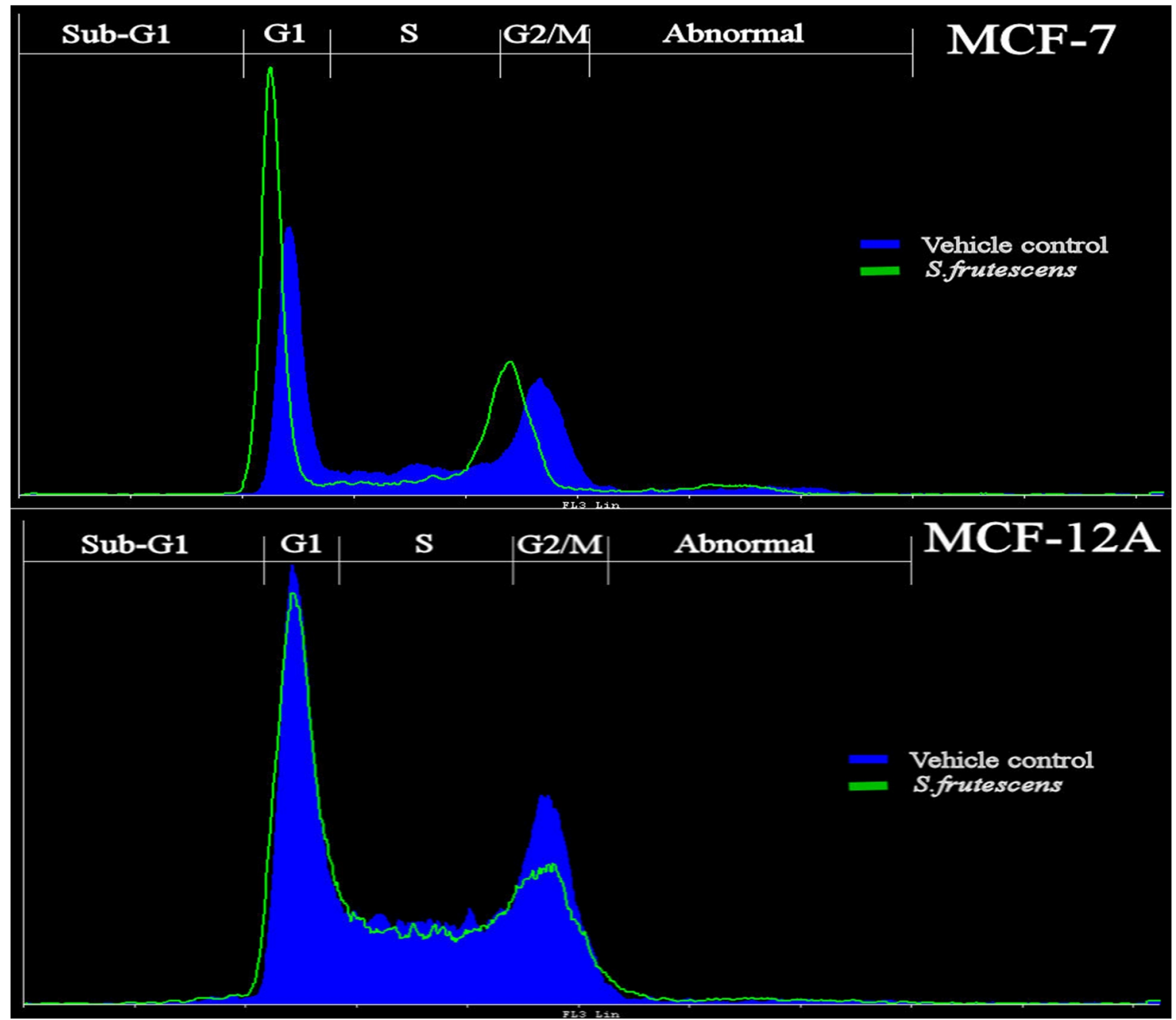

Figure 6: Flow cytometric analysis of cell cycle progression in MCF-7 (top) and MCF-12A (bottom) cells exposed to $\mathrm{H}_{2} \mathrm{O}$ as vehicle control (solid blue area) and $S$. frutescens extracts (green line). Both cell lines exhibited a statistically significant increase in the number of $G_{1}$-phase cells, with concurrent decrease in other phases. 
Table 2: Flow cytometric analyses of cell cycle dynamics

\begin{tabular}{|c|c|c|c|c|c|c|c|c|c|}
\hline \multirow{5}{*}{$\begin{array}{c}\text { Sub-G1 } \\
\%\end{array}$} & \multirow{4}{*}{$\begin{array}{l}X \text { mean } \\
X \text { geo } \\
\text { mean }\end{array}$} & \multicolumn{4}{|c|}{ MCF-7 } & \multicolumn{4}{|c|}{ MCF-12A } \\
\hline & & \multicolumn{2}{|c|}{$\mathrm{H} 2 \mathrm{O}$} & \multicolumn{2}{|c|}{ S. frutescens } & \multicolumn{2}{|c|}{$\mathrm{H} 2 \mathrm{O}$} & \multicolumn{2}{|c|}{ S. frutescens } \\
\hline & & \multirow{3}{*}{$0.14 \%$} & 209.68 & \multirow{3}{*}{$0.49 \%$} & 146.44 & \multirow{3}{*}{$0.87 \%$} & 185.95 & \multirow{3}{*}{$1.52 \%$} & 180.29 \\
\hline & & & 209.01 & & 124.47 & & 184.04 & & 174.62 \\
\hline & cV & & 7.76 & & 43.19 & & 12.93 & & 20.42 \\
\hline \multirow{3}{*}{ G1 \% } & $\mathrm{x}$ mean & \multirow{3}{*}{$39.57 \%$} & 252.99 & \multirow{3}{*}{$51.76 \%$} & 235.64 & \multirow{3}{*}{$37.65 \%$} & 253.78 & \multirow{3}{*}{$42.47 \%$} & 252.42 \\
\hline & $\begin{array}{l}X \text { geo } \\
\text { mean }\end{array}$ & & 252.55 & & 235.1 & & 253.39 & & 251.92 \\
\hline & $\mathrm{cV}$ & & 6.04 & & 7.08 & & 5.5 & & 6.33 \\
\hline \multirow{3}{*}{ S \% } & $x$ mean & \multirow{3}{*}{$20.95 \%$} & 373.11 & \multirow{3}{*}{$16.25 \%$} & 380.45 & \multirow{3}{*}{$31.90 \%$} & 364.16 & \multirow{3}{*}{$30.31 \%$} & 366.57 \\
\hline & $\begin{array}{l}\mathrm{X} \text { geo } \\
\text { mean }\end{array}$ & & 370.23 & & 377.33 & & 361.1 & & 363.29 \\
\hline & cV & & 12.28 & & 12.34 & & 12.91 & & 13.3 \\
\hline \multirow{3}{*}{ G2/M \% } & $\mathrm{X}$ mean & \multirow{3}{*}{$31.83 \%$} & 488.99 & \multirow{3}{*}{$25.06 \%$} & 446.81 & \multirow{3}{*}{$26.88 \%$} & 481.67 & \multirow{3}{*}{$21.51 \%$} & 486.04 \\
\hline & $\begin{array}{l}X \text { geo } \\
\text { mean }\end{array}$ & & 487.51 & & 446.62 & & 481.21 & & 485.37 \\
\hline & $\mathrm{cV}$ & & 8.17 & & 2.88 & & 4.39 & & 5.32 \\
\hline \multirow{3}{*}{ Abn \% } & $X$ mean & \multirow{3}{*}{$7.19 \%$} & 780.73 & \multirow{3}{*}{$6.02 \%$} & 720.49 & \multirow{3}{*}{$2.35 \%$} & 753.25 & \multirow{3}{*}{$3.83 \%$} & 741.14 \\
\hline & $\begin{array}{l}X \text { geo } \\
\text { mean }\end{array}$ & & 776.5 & & 715.6 & & 746.78 & & 735.43 \\
\hline & $\mathrm{cV}$ & & 10.66 & & 12.07 & & 13.17 & & 12.55 \\
\hline
\end{tabular}

\subsubsection{Annexin V-FITC}

Analyses of phosphatidylserine externalization by flow cytometric detection of

Annexin V binding (Fig. 7) revealed a 4.37\% increase in apoptosis in the MCF-7 cell

line in response to $S$. frutescens exposure, with the increase mostly notable in the

early apoptotic phase. The MCF-12A cell line showed no significant changes when samples exposed to $S$. frutescens extracts ( $93.48 \%$ viable) were compared to vehicle control samples ( $94.37 \%$ viable). Data is shown in table 3. 


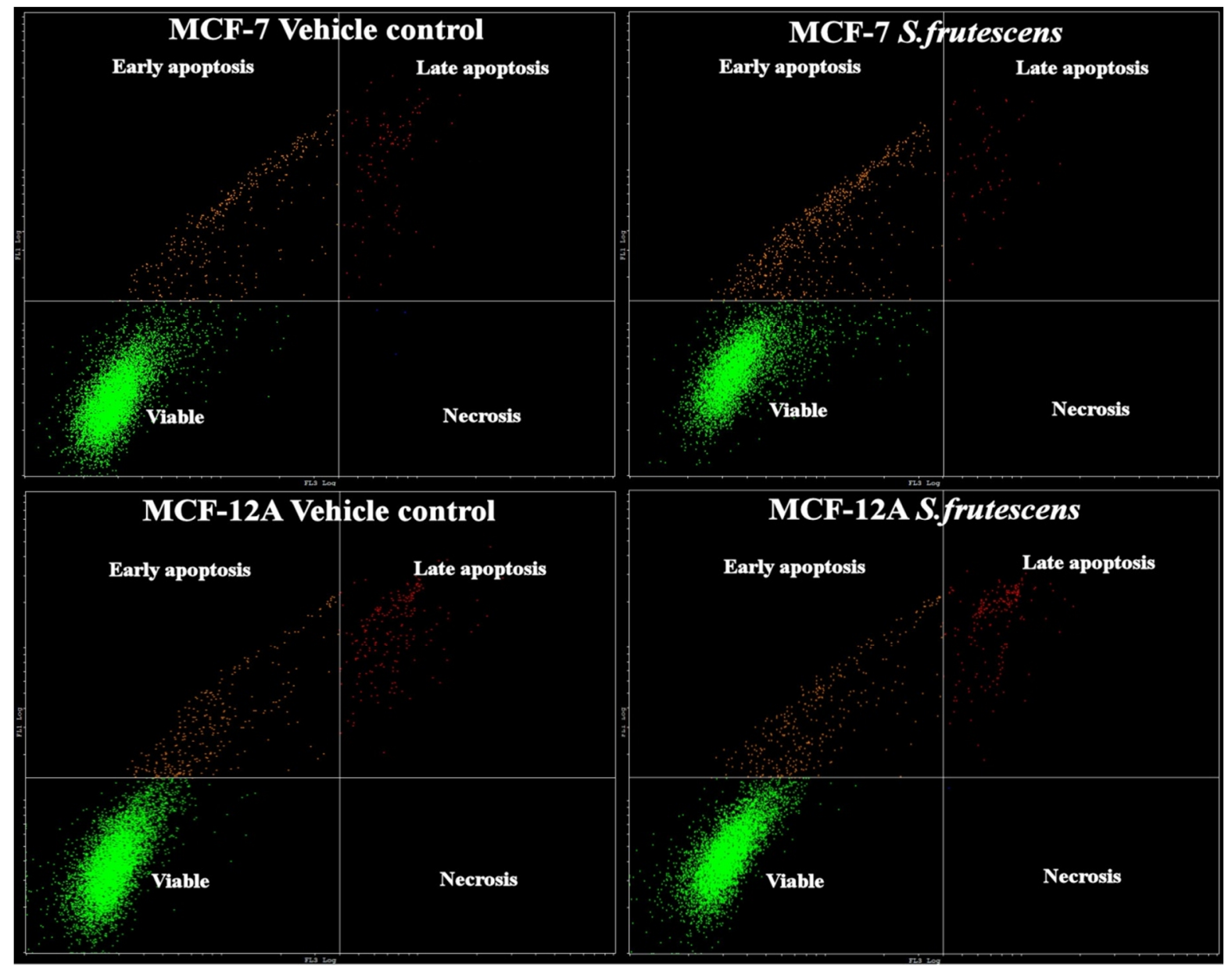

Figure7: Flow cytometric analysis of phosphatidylserine externalization via Annexin $\mathrm{V}$ binding in MCF-7 (top) and MCF-12A (bottom) cells exposed to vehicle control $\left(\mathrm{H}_{2} \mathrm{O}\right.$ - left) and $S$. frutescens extracts (right). MCF-7 samples showed a more distinct increase in apoptotic cells in response to $S$. frutescens exposure when compared to MCF-12A cells.

\section{Discussion}

S. frutescens extracts have shown promising antiproliferative activity in previous studies

(Chinkwo, 2005; Stander et al., 2009; Tai et al., 2004), and significant inroads are being made into understanding the effects of these extracts on cell physiology and whole organism physiology, with data from in vitro studies augmented by experiments conducted in mice, rats and humans (Kundua et al., 2005; Prevoo et al., 2004; Chadwick et al., 2007; Grandi et al., 2005). Our study revealed that aqueous $S$. frutescens extracts affect the proliferation, morphology and cell cycle dynamics of both the MCF-7 breast adenocarcinoma and MCF- 
12A non carcinogenic breast epithelial cell lines to varying degrees in a time-and dose dependent manner.

Table 3: Flow cytometric analyses of phosphatidylserine externalization

\begin{tabular}{|c|c|c|c|c|c|c|c|c|c|}
\hline \multirow{6}{*}{ Viable } & \multirow[b]{3}{*}{$X$ mean } & \multicolumn{4}{|c|}{ MCF-7 } & \multicolumn{4}{|c|}{ MCF-12A } \\
\hline & & \multicolumn{2}{|c|}{$\mathrm{H} 2 \mathrm{O}$} & \multicolumn{2}{|c|}{ S. frutescens } & \multicolumn{2}{|c|}{$\mathrm{H} 2 \mathrm{O}$} & \multicolumn{2}{|c|}{ S. frutescens } \\
\hline & & \multirow{4}{*}{$95.18 \%$} & 2.89 & \multirow{4}{*}{$90.81 \%$} & 3.2 & \multirow{4}{*}{$94.37 \%$} & 2.79 & \multirow{4}{*}{$93.48 \%$} & 2.95 \\
\hline & $\mathrm{X}$ geo mean & & 3.61 & & 4.85 & & 4.08 & & 4.42 \\
\hline & Y mean & & 2.72 & & 2.83 & & 2.64 & & 2.73 \\
\hline & $Y$ geo mean & & 3.13 & & 3.97 & & 3.46 & & 3.69 \\
\hline \multirow{4}{*}{$\begin{array}{c}\text { Early } \\
\text { Apoptosis }\end{array}$} & $\mathrm{X}$ mean & \multirow{4}{*}{$3.61 \%$} & 12.08 & \multirow{4}{*}{$8.29 \%$} & 10.51 & \multirow{4}{*}{$3.29 \%$} & 12.27 & \multirow{4}{*}{$4.01 \%$} & 11.39 \\
\hline & $\mathrm{X}$ geo mean & & 60.21 & & 51.66 & & 55.31 & & 52.61 \\
\hline & Y mean & & 10.1 & & 8.86 & & 10.2 & & 9.51 \\
\hline & $Y$ geo mean & & 48.33 & & 42.6 & & 43.35 & & 42.22 \\
\hline \multirow{4}{*}{$\begin{array}{c}\text { Late } \\
\text { Apoptosis }\end{array}$} & $X$ mean & \multirow{4}{*}{$1.16 \%$} & 70.59 & \multirow{4}{*}{$0.88 \%$} & 67.33 & \multirow{4}{*}{$2.33 \%$} & 72.88 & \multirow{4}{*}{$2.48 \%$} & 72.49 \\
\hline & $X$ geo mean & & 140.06 & & 124.59 & & 116.72 & & 150.75 \\
\hline & Y mean & & 67.28 & & 64.21 & & 68.43 & & 69.1 \\
\hline & Y geo mean & & 111.27 & & 96.16 & & 95.21 & & 125.18 \\
\hline \multirow{4}{*}{ Necrosis } & $\mathrm{X}$ mean & \multirow{4}{*}{$0.03 \%$} & 57.22 & \multirow{4}{*}{$0 \%$} & 57.27 & \multirow{4}{*}{$0 \%$} & 42.17 & \multirow{4}{*}{$0.01 \%$} & 50.13 \\
\hline & $X$ geo mean & & 11.3 & & 13.22 & & 15.73 & & 11.88 \\
\hline & Y mean & & 55.51 & & 55.98 & & 42.16 & & 49.61 \\
\hline & Y geo mean & & 10.57 & & 10.25 & & 15.58 & & 11.88 \\
\hline
\end{tabular}

Evaluation of cellular proliferation by crystal violet staining identified $1 \mathrm{mg} / \mathrm{ml}$ and 48 hours to be the optimal time and dose combination for a comparative study of the effects of $S$. frutescens on the MCF-7 and MCF-12A cell lines. These experiments quantified growth inhibition at the stated parameters to be $48.21 \%$ in the MCF-7 cell line and $6.78 \%$ in the MCF-12A cell line (a difference of 41.43\%). The inhibition of cell division and subsequent proliferation was confirmed by both mitotic index counts and flow cytometric analysis of cell cycle dynamics. Mitotic index counts showed a 5.27\% decrease in actively cycling (dividing) 
cells in the MCF-7 cell line, compared to a $0.1 \%$ increase in the MCF-12A cell line. The observation that cell growth in these two cell lines is differentially affected by exposure to aqueous $S$. frutescens extracts was further confirmed by the increases in $\mathrm{G}_{1}$-phase cells (and subsequent decrease in S-phase and $\mathrm{G}_{2} / \mathrm{M}$-phase cells) brought to light by flow cytometric analysis of cell cycle dynamics (12,19\% increase for MCF-7, 4.82\% increase for MCF-12A). These investigations also revealed an increase in cells with abnormal and apoptotic morphology. Following the results of previous studies such as those by Chinkwo (2005) and Stander et al. (2009), morphological investigation by means of PlasDIC microscopy and haematoxylin and eosin staining showed defined apoptotic characteristics, with hypercondensed and fragmented chromatin, apoptotic blebbing and cellular disintegration. Analyses of intracellular events by means of fluorescence microscopy and flow cytometric externalization of Annexin $\mathrm{V}$ showed the significant induction of autophagy and, to a lesser extent, apoptosis in both cell lines, with the MCF-7 cell line being more susceptible to $S$. frutescens exposure. When the signaling pathways involved in these two distinct, but interlinked processes are taken into account, it seems probable that the exposed cells are using autophagy induction as primarily a survival mechanism. When this fails, cells enter early apoptosis (4.68\% increase in MCF-7, $0.72 \%$ increase in MCF-12A), and subsequent late apoptosis and necrosis, leading to the observed morphological characteristics.

These findings are in concurrence with previous studies which have demonstrated the cytostatic and cytotoxic effects of $S$. frutescens in cervical carcinoma, $\mathrm{CHO}$ Chinese hamster ovary cancer cells, DU-145 prostate cancer cells and MDA-MB-231 breast cancer cells (Chinkwo, 2005; Tai et al., 2004; Steenkamp and Gouws, 2006). In addition, this study yielded a novel finding demonstrating the induction of autophagy in the MCF-7 and MCF12A cell lines using aqueous $S$. frutescens extracts. However the previously observed 
phosphatidylserine externalization when utilizing ethanolic extracts (Chinkwo, 2005; Stander et al., 2009) was observed to a much lesser extent in the current study. This finding could indicate the ethanolic fractionalization of a key effector molecule leading to the promising cancer specific cytotoxic effects previously observed. Furthermore, no S-phase cell cycle arrest was observed in this study (previously reported in studies using ethanolic extracts of $S$. frutescens) (Stander et al., 2009), and the cancer specific cytotoxic effects previously reported in ethanolic extracts appear to be less pronounced when aqueous extracts are utilized. The carcinogenic MCF-7 cell line was, however, clearly more susceptible to the cytostatic effects described.

When taking into account the fact that a single pharmacologically active ingredient responsible for the varied effects of $S$. frutescens has not been isolated and the differing efficacy of ethanolic and aqueous extracts, it becomes apparent that the cumulative combination of the bioactive compounds in plant extracts (Shaik et al., 2010) must be responsible for the promising antiproliferative effects. The concentrations of each of the potentially therapeutic compounds is, to a large extent, dependent on the location (regional differences) and growth conditions (soil conditions, UV exposure etc.) of the individual plant (Moshe et al., 1998). Further complicating the matter is the question of the taxonomic classification of $S$. frutescens into various subspecies (Moshe et al., 1998; Phillips and Dyer, 1934; Goldblatt and Manning, 2000), and the part of the plant (e.g. leaves, stems etc.) from which the extract is derived (Shaik et al., 2010). At this time, no single molecular pathway explaining the effects observed in studies investigating the therapeutic potential of $S$. frutescens seems clear, with several distinct but interlinked mechanisms being the probable answer. 


\section{Conclusions}

This study has broadened the understanding of the previously documented effects of $S$. frutescens extracts by demonstrating that aqueous extracts have a differential influences on proliferation, morphology and cell death in the carcinogenic MCF-7 breast adenocarcinoma cell line when compared to the non-carcinogenic MCF-12A cell line. Due to the lack of a single, clearly elucidated biochemical pathway to account for the observed effects, further in vitro research and biochemical analyses regarding the physiological and molecular mechanisms of this potentially useful and cost-effective natural product are warranted.

\section{Acknowledgements}

This research was supported by grants from the Medical Research Council of South Africa (AK076; AL343), the Cancer Association of South Africa (AK246), the National Research Foundation of South Africa (AL239) and the Struwig-Germeshuysen Cancer Research Trust of South Africa (AN074). The authors would like to thank the Departments of Physiology and Pharmacology of the University of Pretoria for the use of their facilities and expertise.

\section{References}

Androutsopoulos VP, Papakyriakou A, Vourloumis D, Tsatsakis AM, Spandidos DA. Dietary flavonoids in cancer therapy and prevention: Substrates and inhibitors of cytochrome P450 CYP1 enzymes. Pharmacology and therapeutics, 2010; 126, 9-20.

Balunas MJ, Kinghorn AD. Drug discovery from medicinal plants. Life Sciences, 2005; 78, 431-441.

Brown L, Heyneke O, Brown D, van WykJ. Impact of traditional medicinal plant extracts on antiretroviral drug absorption. Journal of Ethnopharmacology , 2008; 119, 588-592.

Chadwick W, Roux S, van de Venter M, Louw J, Oelofsen W. Anti-diabetic effects of Sutherlandia frutescens in Wistar rats fed a diabetogenic diet. Journal of Ethnopharmacology, 2007; 109, 121-127. Chan $P$. Acylation with diangeloyl groups at $\mathrm{C} 21-22$ positions in triterpenoid saponins is essential for cytotoxicity towards tumor cells. Biochemical Pharmacology, 2007; 73, 341-350.

Chinkwo K. Sutherlandia frutescens extracts can induce apoptosis in cultured carcinoma cells. Journal of Ethnopharmacology, 2005; 98, 163-170.

da Rocha A, Lopes R, Schwartsmann G. Natural products in anticancer therapy. Current Opinion in 
Pharmacology, 2001; 1, 364-369.

Grandi M, Roselli L, Vernay M. Lessertia (Sutherlandia frutescens) et la fatigue en cancérologie. Phytothérapie, 2005; 3, 110-113.

Goldblatt P, Manning J. Cape plants. A conspectus of the Cape flora of South Africa. Strelitzia 9, 2000. National Botanical Institute, Pretoria.

Harnett $S$, Oosthuizen $V$, van de Venter $M$. Anti-HIV activities of organic and aqueous extracts of Sutherlandia frutescens and Lobostemon trigonus. Journal of Ethnopharmacology, 2005; 96, 113-119.

Katerere D, Eloff J. Antibacterial and Antioxidant Activity of Sutherlandia frutescens (Fabaceae), A Reputed Anti-HIV/AIDS Phytomedicine. Phytotherapy Research, 2005; 19, 779-781.

Klos M, van de Venter M, Milne PJ, Traore HN, Meyer D, Oosthuizen V. In vitro anti-HIV activity of five selected South African medicinal plants. Journal of Ethnopharmacology, 2009; 124, 182-188.

Kundua J, Mossandab K, Naa H, Surh Y. Inhibitory effects of the extracts of Sutherlandia frutescens (L.) R. Br. and Harpagophytum procumbens DC. on phorbol ester-induced COX-2 expression in mouse skin: AP-1 and CREB as potential upstream targets. Cancer Letters, 2005; 21, 21-31.

Morris K. Treating HIV in South Africa - a tale of two systems. The Lancet, 2001; 357, 9263, 1190.

Moshe D, van der Bank H, van der Bank M, van Wyk B. Lack of genetic differentiation between 19 populations from seven taxa of Sutherlandia Tribe: Galegeae, Fabaceae. Biochemical Systematics and Ecology, 1998; 26 (6), 595-609.

Pervin S, Singh R, Chaudhuri G. Nitric oxide, Nx-hydroxy-L-arginine and breast cancer. Nitric Oxide, 2008; 19, 103-106.

Phillips EP, Dyer RA. The genus Sutherlandia R. Br. Revista. Sudamericana de Botanica, 1934; 1, 69-80.

Prevoo D, Smith C, Swart P, Swart A. The Effect of Sutherlandia frutescens on Steroidogenesis:

Confirming Indigenous Wisdom. Endocrine Research, 2004; 30 (4), 745 - 751.

Shaik S, Singh N, Nicholas A. HPLC and GC analyses of in vitro- grown leaves of the cancer bush Lessertia

(Sutherlandia) frutescens L. reveal higher yields of bioactive compounds. Plant Cell, Tissue and Organ Culture, 2010; DOI 10.1007/s11240-010-9884-4.

Stander A, Marais S, Stivaktas V, Vorster C, Albrecht C, Lottering M. In vitro effects of Sutherlandia frutescens water extracts on cell numbers, morphology, cell cycle progression and cell death in a tumorigenic and a non-tumorigenic epithelial breast cell line. Journal of Ethnopharmacology, 2009; 124 , 45-60.

Steenkamp V, Gouws M. Cytotoxicity of six South African medicinal plant extracts used in the treatment of cancer. South African Journal of Botany, 2006; 72, 630-633.

Tai J, Cheung S, Chan E, Hasman D. In vitro culture studies of Sutherlandia frutescens on human tumor cell lines. Journal of Ethnopharmacology, 2004; 93, 9-19.

van Wyk B, Albrecht $C$. A review of the taxonomy, ethnobotany, chemistry and pharmacology of Sutherlandia frutescens (Fabaceae). Journal of Ethnopharmacology, 2008; 119, 620-629. van Wyk B, Gericke N. People's plants. A guide to the useful plants of Southern Africa. Briza, Pretoria, 2000. Vorster CJJ, Joubert AM. In vitro effects of 2-methoxyestradiol-bis-sulphamate on the non-tumorigenic MCF-12A cell line. Cell Biochemistry and Function, 2010; 28: 412-419. 